Удк 620.168.16

\title{
CORROSION-MECHANICAL DURABILITY OF DETAILS OF EQUIPMENT OF DAIRIES
}

\author{
M. Skyba, N. Stechyshyna \\ Khmelnytskyi National University
}

\begin{tabular}{l}
\hline \multicolumn{1}{c}{ Key words: } \\
cavitation, \\
knowledge, \\
composition of electrical \\
protection (CEP), \\
waterless nitrogen in the \\
last discharge (BATR)), \\
corrosion-mechanical wear \\
resistance (CMZ)
\end{tabular}

Article history:

Received 15.09.2019

Received in revised form

02.11.2019

Accepted 20.11.2019

Corresponding author: av.mart@ukr.net

\begin{abstract}
The types of equipment parts wear in milk processing plant are analyzed depending on the type of environment. Parts of equipment that show the greatest level of depreciation (wear) has been detected.
\end{abstract}

Analysis of food processing industry environments and the specifics of interaction of working parts, equipment surfaces with it allows us to identify six cases of corrosion-mechanical wear (CMW) that occurs in the metal-medium $(\mathrm{M}+\mathrm{M})$ system: corrosion, erosion, cavitation-erosion, chemical -mechanical, gas and hydro-abrasive wear.

To increase the corrosion and cavitation-erosion wear resistance of carbon steels, a technology for applying complex composite coatings (CCC) has been developed. CCCs are formed on the basis of a nickel matrix, which is filled with particles of silicon carbide of different fractional - nano and $5 \mu \mathrm{m}(\mathrm{Ni}+\mathrm{SiCnano}$ and $\mathrm{Ni}+\mathrm{SiC5}$ ), which made it possible to increase the corrosion resistance of steel 45 by $2.4 ; 4.5 ; 3.0 ; 4.8$ times in water, $3 \%$ sodium chloride solution, acidic and alkaline model environments, respectively. It has also been shown that CCCs with SiCnano and SiC5 particles on average increase by 6 times the wear resistance of steel 45 normalized in hard water, 11 times in a $3 \% \mathrm{NaCl}$ solution, and more than 16 times in an acidic medium.

The test results of the impellers and pump covers for the developed Zero-hydrogen nitriding in a glow discharge (BATR) technology at the Khmelnitsky oil and cheese plant when pumping saline solutions showed that their service life increased by 7.4 times, and when pumping tap water by 8.7 times.

Cavitation-erosion wear resistance of $40 \mathrm{X}$ nitrided steel samples by the developed method (medium temperature shock tests and BATP at $520^{\circ} \mathrm{C}$ ) increased 1.5 times in 3 hours of testing in a cheese dairy, with the known ion nitriding method.

DOI: $10.24263 / 2225-2916-2019-26-15$

(c) М. С. Скиба, Н. М. Стечишина, 2019 


\title{
КОРОЗІЙНО-МЕХАНІЧНА ЗНОСОСТІЙКІСТЬ ДЕТАЛЕЙ ОБЛАДНАННЯ МОЛОКОЗАВОДІВ
}

\author{
М. Є. Скиба, д-р техн. наук \\ Н. М. Стечишина \\ Хмельницький національний університет
}

Проаналізовано види зношування деталей обладнання молокозаводів залежно від виду середовища. Виявлено найбільш зношувані деталі. Для підвищення корозійної та кавітаційно-ерозійної зносостійкості вуглецевих сталей розроблено технологію нанесення комплексних композиційних покриттів (КЕП). Запропоновано методи зміцнення металевих поверхонь - безводневе азотування в тліючому розряді (БАТР) та нанесення композиційних електролітичних покриттів.

Результати випробувань робочих коліс $і$ кришок за розробленою технологією БАТР на Хмельницькій маслосирбазі при перекачуванні соляних розчинів показали, що термін їх служби збільшується в 7,4 раза, а при перекачуванні водопровідної води - у 8,7 раза. Кавітаційно-ерозійна зносостійкість азотованих зразків сталі 40Х розробленим способом (середньотемпературна ТЦО та БАТР при $520^{\circ} \mathrm{C}$ ) збільшилася в 1,5 раза за 3 год випробувань у сироватиі, порівняно з відомим способом іонного азотування.

Ключові слова: кавітація, зношування, композиційні електролітичні покриття (КЕП), безводневе азотування в тліючому розряді (БАТР), корозійно-механічна зносостійкість (КМЗ).

Постановка проблеми. Однією 3 найважливіших проблем підвищення надійності і довговічності обладнання харчових виробництв є підвищення корозійномеханічної зносостійкості (КМЗ) деталей, які контактують з корозійно-активними середовищами підприємств харчової промисловості. Зупинка обладнання спричиняє великі збитки не лише внаслідок зменшення об'єму продукції, але й від можливого псування продуктів переробки.

На ремонт обладнання, підтримку його працездатності в системі Мінагропрому протягом 6 років витрачаються кошти, що дорівнюють вартості виробничих фондів усієї галузі [1].

У загальній проблемі підвищення надійності і довговічності роботи обладнання харчових виробництв важливе значення має підвищення зносостійкості деталей обладнання молокозаводів, які підлягають корозійно-механічному зношуванню при контакті із специфічними хімічно-активними середовищами виробництва молочних і кисло-молочних продуктів.

М. М. Хрущов вперше виділив КМЗ як окремий вид зношування, де вказується, що механічне зношування, підсилене явищами корозії, $є$ корозійно-механічним. Також дослідник виділяє групи видів КМЗ і зауважує, що у випадку КМЗ основною $\epsilon$ взаємодія середовища 3 матеріалами тіл, які труться, 3 подальшим механічним видаленням продуктів взаємодії.

На сьогодні КМЗ - один із видів зношування, закріплений ГОСТ 23.002-72, де він розглядається не лише, як процес тертя між двома металами, в зону контакту яких проникають корозійно-активні середовища, тобто в системах метал+ + середовище+метал $(\mathrm{M} 1+\mathrm{C}+\mathrm{M} 2)$, але і в системах метал + середовище $(\mathrm{M}+\mathrm{C})$. Так, 
у [2] виділено п'ять випадків КМЗ металевих деталей, зокрема «корозійну кавітацію» і «корозійну ерозію».

На основі узагальнення власних експериментальних досліджень і аналізу праць наукової школи Г. О. Прейса та зарубіжних учених [3-7] розроблена схема перебігу процесів КМЗ при терті та при кавітаційно-ерозійному зношування [8; 9].

Враховуючи, що процеси руйнування при зношуванні починаються 3 поверхневих шарів металів основна увага приділена таким, на думку авторів, найбільш перспективним способам поверхневого зміцнення, як формування на металах композиційних електролітичних покриттів (КЕП) та застосування безводневого азотування в тліючому розряді (БАТР).

Мета дослідження: на основі обстеження деталей обладнання молокозаводів визначити вид та інтенсивність зношування залежно від електрохімічних характеристик середовища і навантаження їх поверхонь та розробити технології поверхневого зміцнення.

Матеріали і методи. Досліджували вуглецеві сталі 20, 45, 40X, сірий чавун СЧ20 при їх контакті з середовищами молокозаводів. Проводили візуальний огляд поверхонь зношування, електрохімічні вимірювання, рентгеноструктурний аналіз зношених поверхонь, хімічний аналіз продуктів зношування.

Результати досліджень. Основним технологічним середовищем молокопереробних виробництв $є$ молоко, яке складається 3250 основних компонентів: 25 основних жирних кислот, 20 амінокислот, 25 молочного цукру, 45 мінеральних речовин і мікроелементів, 25 вітамінів, значної кількості важливих для обміну речовин ферментів і гормонів, а також містить імунні тіла, пігменти, фосфатиди, лимонну, щавлеву та інші кислоти і гази.

Молоко є неоднорідною біологічною рідиною, полідисперсною системою, в якій окремі компоненти знаходяться у різному ступені подрібнення. Дисперсна система складається 3 двох основних частин: води або плазми (дисперсійне середовище і компоненти молока) і дисперсна фаза (сухі речовини).

Вміст води в молоці коливається від 83 до 89\% і вона може бути вільною, зв’язаною, набухання і кристалізаційною [10].

До складу сухих речовин входять усі компоненти молока (білок, жир, молочний цукор, мінеральні солі тощо). Від вмісту сухих речовин залежить поживна цінність молока. За вмістом сухих речовин (СР) обчислюють вихід готових молочних продуктів.

Найбільш перемінною складовою частиною молока є жир (ліпіди), вміст якого сягає 2,7...6,0\% і який складається на 97,5\% 3 простих і 2,5\% складних ліпідів [10]. Перші являють собою складні ефіри спирту і жирних кислот, а другі - ефіри, в яких жирні кислоти з'єднані з гліцерином.

Молоко містить також білкові і небілкові азотисті з’єднання (2,2..4,0\%), моносахариди $(4,0 \ldots 5,5 \%)$, які є основою процесу бродіння для одержання сиру, кисломолочних продуктів, молочних напоїв, а також мінеральних речовин і солей (біля 1\%). У молоко входить до 80 елементів періодичної системи Менделєєва [11].

Густина молока знаходиться в межах 1027...1032 кг/м3 при температурі 200С, а його кислотність РН 6,3...6,9. Тобто молоко має слабокислу реакцію [10]. Крім того, молоко має буферні властивості, які обумовлені наявністю білків і фосфатів [11]. 
Залежно від температурного режиму обробки виробляється пастеризоване, топлене і стерилізоване питне молоко.

Пастеризоване молоко (нагрів до температур не вище $100^{\circ} \mathrm{C}$ з різною витримкою) випускається у виді цільного, підвищеної жирності, білкового, вітамінізованого, нежирного. Цільне молоко може буги натуральним, нормалізованим і відновленим, які відрізняються, в основному, вмістом жиру, білка та вмістом сухих речовин. Кислотність різних видів молока становить РН 6,5, а для молока підвищеної жирності - PН 6,9 [11].

Більша частина молока підлягає переробці, в результаті якої отримують основний продукт і побічний (вторинний). При виробництві вершків, сметани побічним продуктом є знежирене молоко, при виготовленні масла - знежирене молоко і маслянка, а при отриманні сиру, казеїну — сироватка.

Кисломолочні продукти залежно від виду бродіння поділяються на продукти лише молочнокислого бродіння (кисле молоко, йогурт, сир, сметана) і продукти змішаного бродіння (кефір, кумис). У процесі виробництва цих продуктів, крім кисломолочного бродіння, відбувається спиртове, тож разом з молочною кислотою утворюються леткі кислоти, етиловий спирт і вуглекислий газ [10]. Кисломолочні продукти виготовляють 3 пастеризованого молока.

Молочні продукти необхідної якості характеризуються такими показниками PH: питне молоко $-6,6 \ldots 6,8$; йогурт $-4,0 \ldots 4,3$; закваска $-4,4 \ldots 4,6$; маслянка від солодковершкового масла $-6,4 \ldots 6,6$; кисломолочні вершки $-4,6 \ldots 4,9$; сироватка - 4,3...6,5 [12].

У молочній промисловості широко застосовують розчини хлориду натрію різної концентрації: від 0,5...2,5\% - при виробництві масла, $1,5 \ldots 8 \%$ - при виробництві твердого сиру, а розсоли для посолу сирів містять до $22 \% \mathrm{NaCl}$ [12]. Крім того, для підтримки санітарного стану приміщень, ємностей, апаратури й обладнання підприємств молочної промисловості широко використовують миючі засоби.

За призначенням у технологічному процесі галузі робочі середовища поділяються на три класи: 1 - молоко і молочні продукти (пастеризоване i стерилізоване молоко, сметана, масло, кисло-молочні продукти, сири, казеїн, альбумін тощо); 2 - технологічні водяні розчини (росоли, холодна і горяча вода, пара, волога насичена атмосфера тощо); 3 - органічні і неорганічні миючі засоби (кальцинована сода, їдкі луги, силікати, фосфати, азотна, соляна, фосфорна та інші кислоти).

Таким чином, середовища молочних виробництв надзвичайно різноманітні за своїм складом, фізико-механічними, хімічними і електрохімічними властивостями і відносяться до середовищ 3 нейтральними, кислими та лужними реакціями.

Аналіз видів середовищ молочної промисловості й особливостей взаємодії 3 нею робочих органів, деталей, поверхонь обладнання дає змогу виділити шість випадків корозійно-механічного зношування (КМЗ), які проходять у системі метал-середовище $(\mathrm{M}+\mathrm{C})$ : корозійне, ерозійне, кавітаційно-ерозійне, хімікомеханічне, газо- і гідроабразивне зношування (рис. 1). 


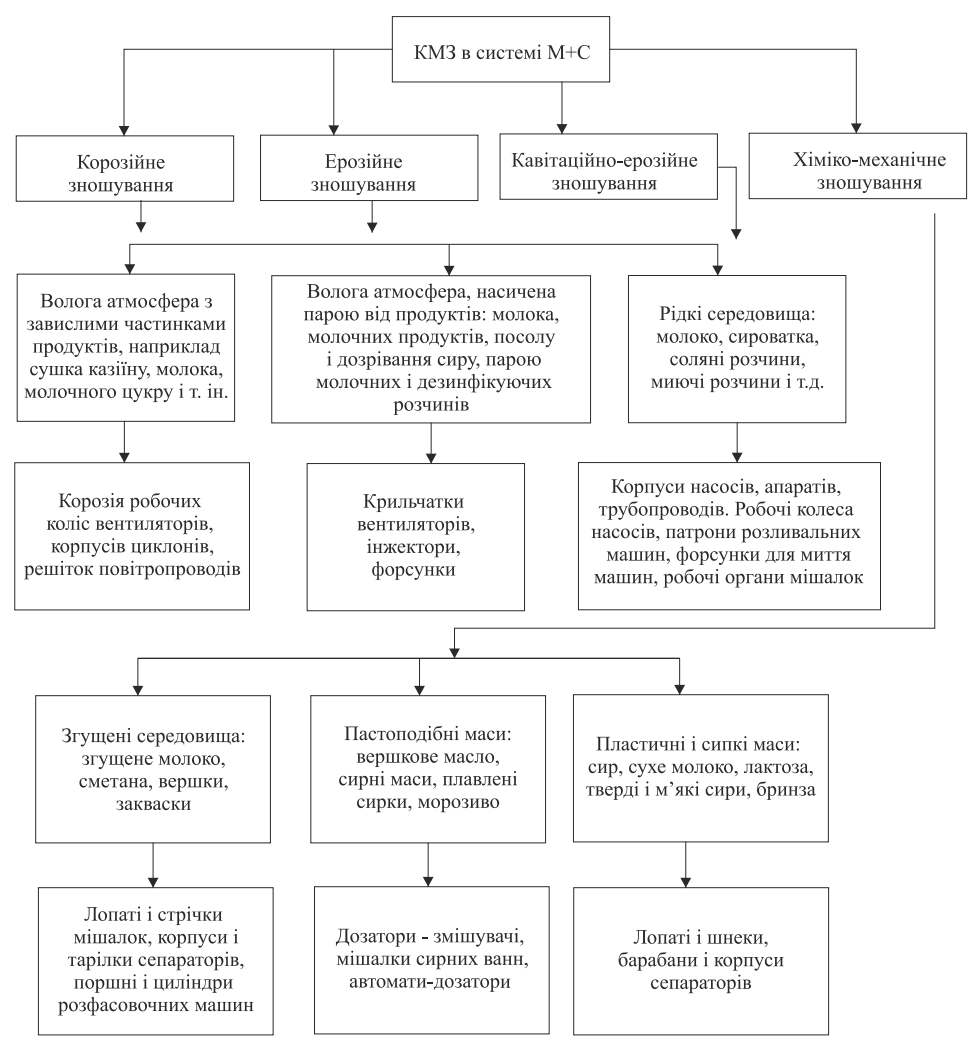

Рис. 1. Схема підвидів КМЗ у системі М - С обладнання молокозаводів

Проведене розділення середовищ молочної промисловості дещо умовне. Так, корозійне, ерозійне і кавітаційно-ерозійне зношування у вологій атмосфері і рідких середовищах при великих швидкостях відносного переміщення деталей і середовища переважає газо- і гідроерозійне, або при наявності абразивних частинок, гідроабразивне або кавітаційно-ерозійне зношування. При невисоких швидкостях — корозійне зношування.

Аналіз зношених деталей у згущених, пастоподібних, пластичних і в сипких середовищах показав, що вони підлягають інтенсивному зношуванню, яке за своїм характером та інтенсивністю суттєво відрізняється від інших видів КМЗ. Такий вид КМЗ вперше виділено Г. О. Прейсом, який назвав його хіміко-механічним (рис. 1). У згущених середовищах (згущене молоко, сметана, вершки) такому виду зношування підлягають лопаті і стрічки мішалок, корпуси і тарілки сепараторів, поршні та циліндри фасувальних машин. У пастоподібних масах (вершкове масло, сирні маси, плавлені сирки, морозиво) найбільш інтенсивно зношуються мішалки сирних мас, дозатори-змішувачі, а в пластичних і сипких продуктах (сир, сухе молоко, лактоза, бринза) - лопаті та шнеки, барабани і корпуси сепараторів. Основний вид зношування при цьому корозійний, а супутній — механічне руйнування утворених продуктів корозії. 
На основі обстеження умов роботи обладнання молокозаводів та аналізу літератури встановлено, що у більшості випадків переважає корозійно-механічне зношування, але його часто супроводжують втомне, ерозійне, гідроабразивне, окисне, корозійне та ін. Так, корозійне зношування деталей внаслідок їх контакту з вологою атмосферою із завислими частинками продуктів при сушщі молока, казеїну, молочного цукру викликає корозію робочих коліс вентиляторів, корпусів циклонів, решіток повітропроводів. Волога атмосфера насичена парою від молока, молочних продуктів, посолу і дозрівання сиру, парою дезинфікуючих розчинів $\epsilon$ також причиною ерозійного зношування крильчаток вентиляторів, інжекторів $\mathrm{i}$ форсунок. Рідкі середовища - молоко, сироватка, соляні та миючі розчини, молочна кислота тощо приводять до кавітаційно-ерозійного зношування корпусів насосів, апаратів, трубопроводів, робочих коліс насосів.

Для зміцнення поверхонь деталей молокозаводів проведено дослідження впливу безводневого азотування в тліючому розряді (БАТР) на фізико-хімічні характеристики металів.

Рентгеноструктурним аналізом встановлено, що незалежно від складу газової атмосфери в поверхневому шарі утворюється $\varepsilon\left(\mathrm{Fe}_{2-3} \mathrm{~N}\right), \gamma /\left(\mathrm{Fe}_{4} \mathrm{~N}\right) \mathrm{i} \alpha-$ фази. При цьому фазовий склад і співвідношення фазових структур в азотованому шарі можна регулювати шляхом зміни режимних параметрів азотування Т, С і р (рис. $2, a, b, c$ ).

Аналіз отриманих залежностей показує, що найбільш суттєво впливає на кількість утворення тих чи інших фаз температура процесу іонного азотування. Так, 3 іiі підвищенням, зменшується кількість є-фази в поверхневому шарі (рис. 2, a) і одночасно збільшується кількість $\gamma /$ і $\alpha-$ фаз (рис. $2, b$, c). Із збільшенням вмісту азоту і тиску газової суміші збільшується кількість $\varepsilon-$ фази (рис. 2, a) і зменшується кількість $\gamma /$ - фази (рис. $2, b$ ). При цьому концентрація азоту і тиск газової суміші практично не впливає на вміст $\alpha-$ фази (рис. 2, c), кількість якої контролюється лише температурою іонного азотування в тліючому розряді, яка, у свою чергу, залежить від енергетичних характеристик процесу (густини струму і напруження на електродах газорозрядної камери).

Завдяки різкій різниці фізико-хімічних властивостей фазових структурних складових азотованого шару і регулюванню їх кількості і співвідношення між ними з'являються широкі можливості для отримання шарів із заданими характеристиками поверхонь.

Як показали дослідження [5; 13], структура азотованого шару і його фазовий склад визначають експлуатаційні характеристики виробів. Зокрема, для відкритих пар тертя (зубчасті колеса, зірочки ланцюгових передач, пальці конвеєрів тощо) застосовуються деталі з високою твердістю, сформовані на основі $\varepsilon-$ фази $\left(\mathrm{Fe}_{2} \mathrm{~N}\right)$. Для закритих пар тертя (підшипники ковзання, зубчасті колеса, коробки передач тощо) необхідне формування азотованого шару з розвинутою нітридною зоною, яка складається з малоазотистих пластичних нітридних фаз $\gamma$ i $\gamma /\left(\mathrm{Fe}_{3} \mathrm{~N} \mathrm{i} \mathrm{Fe}{ }_{4} \mathrm{~N}\right)$, які добре приробляються та локалізують пластичні деформації і перешкоджають розвитку процесу руйнування деталі.

Основний внесок у підвищення границі витривалості при знакозмінних навантаженнях має зона внутрішнього азотування ( $\alpha-$ фаза). Для підвищення жароміцності також основне значення має зона внутрішнього азотування, але 2-го роду, тобто коли утворюються нітриди легуючих елементів $\mathrm{TiN}, \mathrm{ZrN}$ i HfN [13].

У випадку експлуатації деталей у корозійних середовищах при підвищених температурах бажано отримувати дифузійні шари з поверхневою нітридною зоною. 


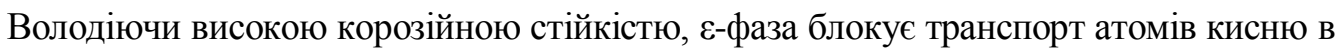
матрицю і перешкоджає дії ефекту адсорбційного пониження міцності (ефект Ребіндера) в статичних умовах і в умовах дії знакозмінних напружень [4; 13].
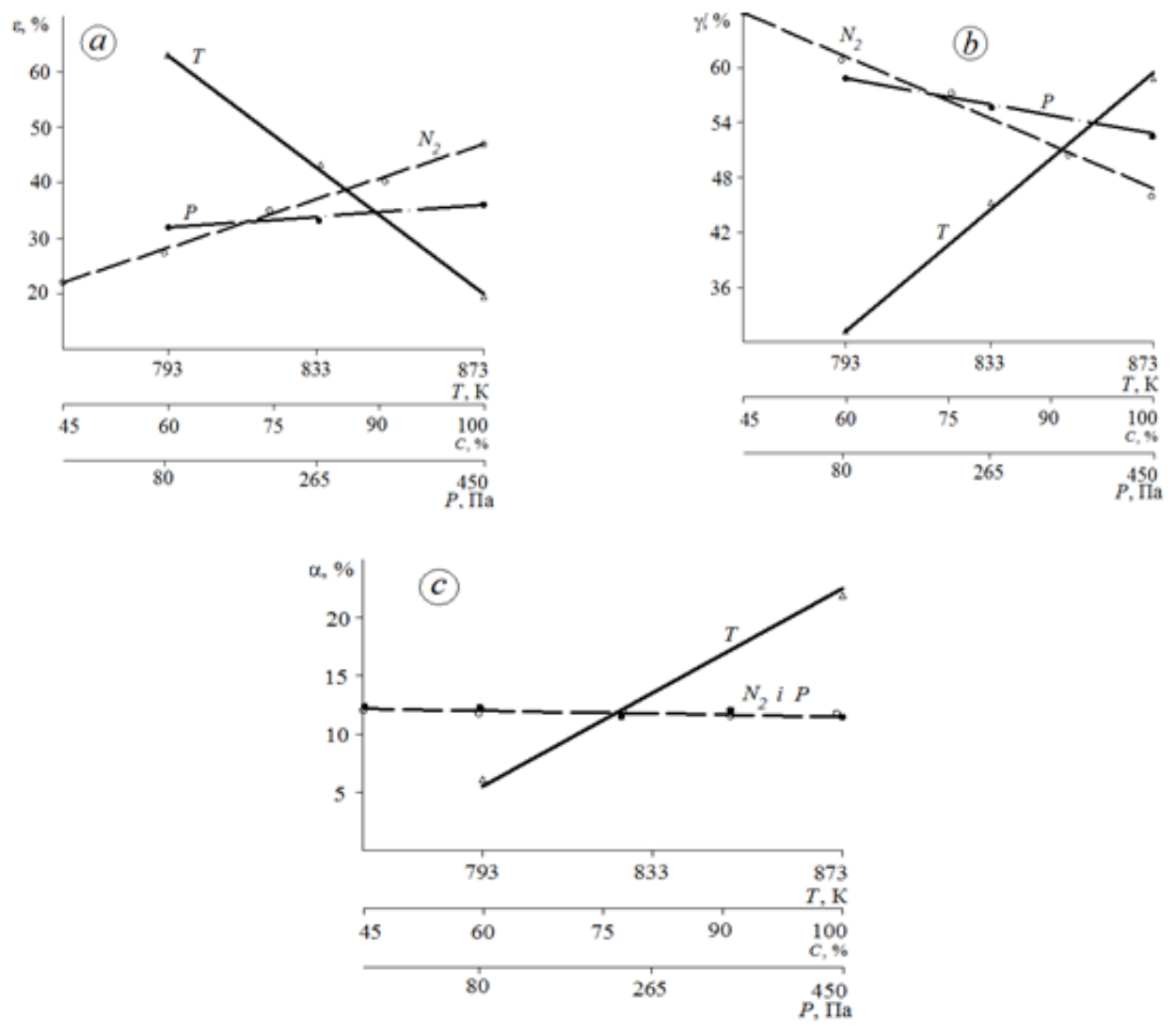

Рис. 2. Залежність фазового складу дифузійного шару сталі $40 \mathrm{X}$ від режимів іонного азотування $(\boldsymbol{T} ; \boldsymbol{C} ; \boldsymbol{p}): a$ ) вміст $\varepsilon$-фази, $b$ ) $\gamma^{\prime}$-фази і $\left.c\right) \alpha$-фази, \%

Проведені дослідження показують, що фазовий склад і співвідношення фазових структур в азотованому шарі можна регулювати шляхом зміни параметрів БАТР: складу газової атмосфери в камері, тиску і температури.

Аналіз отриманих даних також показує, що найбільш суттєво впливає на кількість утворених тих чи інших фаз температура БАТР. Так, з їі підвищенням зменшу-

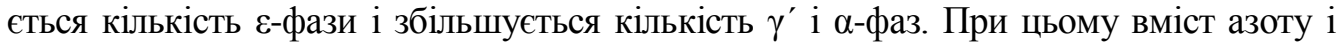
тиск газової суміші не впливає на кількість $\alpha$-фази, вміст якої контролюється лише температурою процесу азотування [5]. Проведені дослідження вказують і на те, що товщина нітридної зони, загальна товщина дифузійного шару, мікротвердість поверхні, величина і характер розподілу напружень стиску контролюються, в основному, температурою процесу азотування.

Вище сказано, що максимум внутрішніх напружень стиску знаходиться на віддалі $10 \ldots 15$ мкм від поверхні, тобто після проходження $\xi$ і $\varepsilon-$ фаз. $\xi-$ фаза утворюється в результаті фазової перекристалізації при охолодженні в тих областях $\varepsilon$ - фази, де концентрація азоту складає $11 \ldots 11,35 \%$ по масі [13]. $\xi$ і $\varepsilon-$ фази 
містять велику кількість пор, стінки яких окиснені. Окиснення стінок пор проходить при охолодженні зразків на поверхні внаслідок того, що поверхневі об'єми $\varepsilon-$ фази з'єднані з поверхнею каналами, які пропускають кисень повітря. Таким чином, у процесі зародження і розвитку фаз проходить релаксація залишкових напружень і ïx зсув в глибину дифузійного шару. Наявність цих мікропор і мікротріщин сприяє інтенсивному корозійно-механічному зношуванню, особливо на початковому етапі циклічних навантажень при терті та кавітації. Отже, зменшення температури азотування призводить до збільшення максимуму залишкових внутрішніх напружень, що спричиняє зменшення поверхневої мікропористості і збільшення циклічної довговічності поверхні.

Випробовування на кавітаційно-ерозійну зносостійкість азотованих зразків СЧ20 в 3\% розчині хлориду натрію показали, що зносостійкість зміцнених зразків майже в 9 разів вища порівняно з неазотованими (рис. 3, а). Кавітаційно-ерозійна зносостійкість сталей 20 і 45 в цьому ж середовищі після азотування зросла в 4,7 і 5,3 раза відповідно (рис. 3 , б). Останнє пояснюється підвищенням фізико-механічних корозійних і втомних характеристик азотованого шару поверхонь металів.

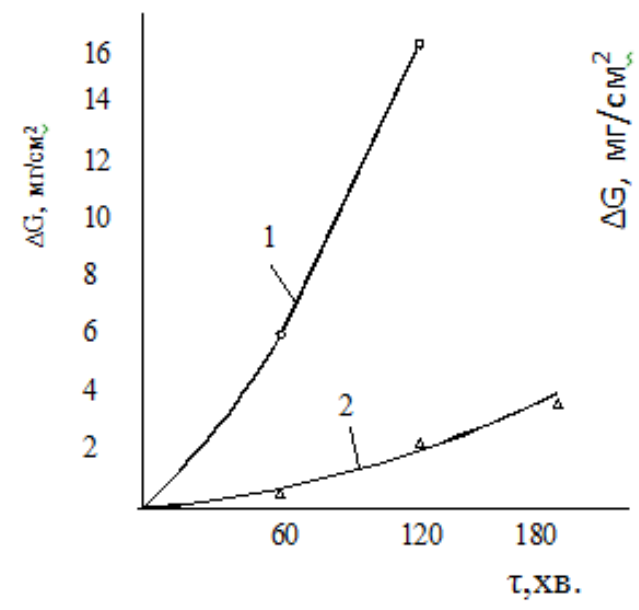

a)

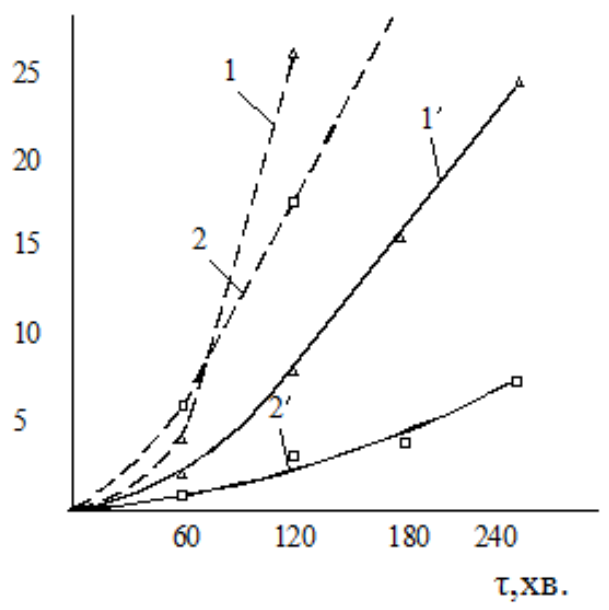

6)

Рис. 3. а) кавітаційно-ерозійна зносостійкість сірого чавуну СЧ20:

1 - до азотування і 2 - після азотування;

б) сталей: 1 і 1'- сталь 20; 2 і 2'- сталь 45 відповідно до і після азотування в $3 \%$ розчині кухонної солі

Результати випробувань робочих коліс і кришок за розробленою технологією БАТР на Хмельницькій маслосирбазі при перекачуванні соляних розчинів показали, що термін їх служби збільшується в 7,4 раза, а при перекачуванні водопровідної води у 8,7 раза.

Для підвищення корозійної та кавітаційно-ерозійної зносостійкості вуглецевих сталей також розроблена технологія нанесення комплексних композиційних покриттів (КЕП). КЕП сформовані на основі нікелевої матриці, що наповнена частинками карбіду кремнію різної фракційності - нано і 5мкм (Ni+SiCнано та $\mathrm{Ni}+\mathrm{SiC} 5)$, які дає змогу збільшити корозійну стійкість сталі 45 в 2,4; 4,5; 3,0; 4,8 раза у воді, 3\% розчині кухонної солі, кислому і лужному модельних середовищах 
відповідно. Також показано, що КЕП з частинками $\mathrm{SiCHaно} \mathrm{SiC}_{5}$ в середньому в 6 разів підвищують зносостійкість сталі 45 нормалізованої в жорсткій воді, в 11 разів в 3-відсотковому розчині $\mathrm{NaCl}$ і більше ніж в 16 разів - у кислому середовищі [9].

Результати випробувань робочих коліс і кришок за розробленою технологією БАТР на Хмельницькій маслосирбазі при перекачуванні соляних розчинів показали, що термін їх служби збільшується в 7,4 раза, а при перекачуванні водопровідної води - у 8,7 раза.

Кавітаційно-ерозійна зносостійкість азотованих зразків сталі $40 X$ розробленим способом (середньотемпературна ТЦО та БАТР при $520^{\circ} \mathrm{C}$ ) збільшилася в 1,5 раза за 3 год випробувань у сироватці, порівняно з відомим способом іонного азотування [9].

\section{ЛIТЕРАТУРА}

1. Елагина О. Ю. Технологические методы повышения износостойкости деталей машин: учеб. пособие / О. Ю. Елагина. - М.: Университетская книга; Логос, 2009. 488c.

2. Томашов Н. Д. Коррозия и коррозионностойкие сплавы. Сер. «Успехи современного металловедения» / Н. Д. Томашов, Г. П. Чернова. - М.: Металлургия, 1973. — 232c.

3. Сологуб Н. А. Прогнозирование и повышение долговечности деталей технологического оборудования сахарных заводов: дис. в форме научного доклада на здобуття наук. ступеня докт. техн. наук: спец. «Машини і апарати харчової промисловості» / Н. А. Сологуб. - К., 1993. - 57c.

4. Некоз А. И. Разработка методов оценки и повышения долговечности деталей оборудования пищевой промышленности, подверженных кавитационно-эрозионному изнашиванию: автореф. дис. на соискание. ступени докт. техн. наук: спец. «Машины и аппараты пищевой промышленности» / А. И. Некоз. - К., 1985. — 43c.

5. Стечишин М. С. Довговічність деталей обладнання харчової промисловості при корозійно-механічному зношуванні: автореф. дис. на здобуття ступеня докт. техн. наук: спец. «Тертя та зношування в машинах» / М. С. Стечишин. - Хмельницький, 1998. 32c.

6. M. Reyes and A. Neville, "Mechanisms of Erosion-Corrosion on a Cobalt-Base Alloy and Stainless-Steel UNS S17400 in Aggressive Slurries” J. Mater. Eng. Perform., vol. 10, no. December, pp. 723—730, 2001.

7. D. Kumar Goyal, H. Singh, H. Kumar, and V. Sahni, "Slurry erosion behaviour of HVOF sprayed WC-10Co-4Cr and $\mathrm{Al} 2 \mathrm{O} 3+13 \mathrm{TiO} 2$ coatings on a turbine steel” Wear, vol. 289, pp. 46-57, 2012.

8. Прейс Г. А. О коррозионно-механическом изнашивании металлов. / Г. А. Прейс, А. Б. Новицкий // Пробл. трения и изнашивания. Респ. Межвед. науч. - техн.сб., 1982. - Вып. 22. - С. 3-8.

9. Стечишин М. С. Кавітаційно-ерозійна зносостійкість деталей обладнання молокозаводів: монографія / М. С. Стечишин, Н. М. Стечишина, А. В. Мартинюк. - Хмельницький: ХНУ, 2018. - 148c.

10. Горбатова К. К. Биохимия молока и молочных продуктов. / К. К. Горбатова. М.: Лег. и пищ. пром-сть, 1984. - 344c.

11. Барабанщиков И. В. Молочное дело / И. В. Барабанщиков. - М.: Колос, 1983. — $414 \mathrm{c}$.

12. Галат Б. Ф. Справочник по технологии молока. / Галат Б. Ф., Машкин Н. И., Козача Л. Г.-К.: Урожай, 1990. - 192с.

13. Лахтин Ю. М. Структура и прочность азотированных сплавов / Ю. М. Лахтин, Я. Д. Коган. - М.: Металлургия, 1982. - 176с. 


\title{
КОРРОЗИОННО-МЕХАНИЧЕСКАЯ ИЗНОСОСТОЙКОСТЬ ДЕТАЛЕЙ ОБОРУДОВАНИЯ МОЛОКОЗАВОДОВ
}

\author{
Н. Е. Скиба, Н. М. Стечишина \\ Хмельницкий национальный университет
}

Проанализированы среды молокозаводов и виды изнашивания деталей их оборудования. Выявлены наиболее изнашиваемые детали. Для повышения коррозионной и кавитационно-эрозионной износостойкости углеродных сталей разработана технология нанесения комплексных композиционных покрытий (КЭП).

Результаты испытаний рабочих колес і крышек насосов за разработанной технологией БАТР на Хмельницкой маслосырбазе при перекачивании солевых растворов показали, что срок их службы увеличился в 7,4 раза, а при перекачивании водопроводной воды - в 8,7 раза. Кавитационно-эрозионная износостойкость азотированных образцов стали 40Х разработанным способом (среднетемпературная ТЦО и БАТР при $520^{\circ} \mathrm{C}$ ) увеличилась в 1,5 раза за 3 ч испытаний в сыворотке, в сравнении с известным способом ионного азотирования.

Ключевые слова: кавитация, износ, композиционные электролитические покрытия (КЭП), безводородное азотирование в тлеющем разряде (БАТР)), корозионномеханическая износостойкость (КМЗ). 